\title{
NOTES ON HIPPOBOSCIDAE
}

\section{ON THE LARger SPECIES OF LYNCHIA WEYENBERGH (OLFERSIA OF AUTHORS; ICOSTA SPEISER; ORNITHOPONUS ALDRICH)}

\author{
BY J. BEQUAERT \\ Department of Tropical Medicine, \\ Harvard Medical School, Boston, Mass.
}

On size alone, most of the species of Lynchia may be divided rather readily into two groups. Although this arrangement disregards true relationship, I shall use it for the purpose of this paper, which discusses only the larger forms of the genus. These are $10 \mathrm{~mm}$. or more in length, as measured from the tip of the fronto-clypeus to the tips of the folded wings. The length of the wing, a much more reliable standard, varies from 6 to $8.5 \mathrm{~mm}$. in the specimens I have seen. L. pilosa (Macquart) is the smallest member of the group known to me. L. penelope Weyenbergh, the unrecognized genotype, also belongs to this group.

I have seen specimens of the six species included in the subjoined key. Having studied much material, I am inclined to regard most of the other names proposed for large Lynchix, as synonyms and I have attempted to treat them accordingly. In many cases the identity of these names must remain open to question, until the original specimens can be examined. I have seen the types of Hippobosca bubonis Packard and Hippobosca nigra Perty only.

1. Mesonotum and scutellum covered fairly uniformly with soft, short hairs, directed backward; scutellum without median groove. Frons very wide, with the sides distinctly converging below; postvertex very short and wide, about one-fourth of the length of the medio-vertex; inner orbital bristles of frons very numerous, in several irregular rows; palpi short, slightly shorter 
than the fronto-clypeus. Basal two-thirds of wing almost destitute of setulæ on the upper side; second basal cell (M) only about one-third the length of the first $(R)$; subcosta (SC) complete, ending in costa. Wing 6 to $6.5 \mathrm{~mm}$. long. African species

L. pilosa (Macquart).

Mesonotum almost bare, except for patches of hairs behind the humeri and before the scutellum; scutellum with a distinct median depression, groove or furrow, the disk bare except for a pair of lateral setæ and an apical fringe of soft hairs. Palpi as long as or longer than fronto-clypeus. Upper side of wing mostly covered with setulæ, except the axillary cell $(2 d \mathrm{An})$ or this cell and the posterior fourth to half of the anal cell $(\mathrm{Cu}+1$ st $\mathrm{An})$

2. Upper side of wing mostly covered with setulæ; only the axillary cell $(2 \mathrm{~d} A n)$ bare. Inner orbital bristles of frons fairly numerous, mostly in one row, but a few forming an incomplete second row. Subcosta (SC) complete, ending in costa. Frons nearly twice as wide as an eye, with subparallel sides. Postvertex rather short, the anterior margin longer than each of the sides. Wing 7 to $8 \mathrm{~mm}$. long

L. palustris (Lutz, Neiva and Costa Lima). Axillary cell and posterior fourth to half of anal cell bare

3.

3. Bristles on inner margin of orbital plates few in number, placed mostly in one, irregular row. Subcosta (or auxiliary vein; SC) incomplete, not ending in costa.. 4. Inner orbital bristles of frons numerous, placed in more than one row. Subcosta (SC) complete, ending in costa. Frons about one and a half times to twice as wide as an eye; inner orbits distinctly diverging toward vertex

4. Inner orbits subparallel. Smooth postvertex rather long, semi-elliptical, with broadly rounded anterior angles, the anterior margin about as long as the sides; with a rudimentary ocellus in a median pit. Wing 6.5 to 7 $\mathrm{mm}$. long L. fusca (Macquart). 
Inner orbits very distinctly diverging toward the vertex. Smooth postvertex rather short, transversely elongate, the anterior angles abruptly rounded off, the anterior margin rather straight and longer than each of the sides; without median pit and rudimentary ocellus. Wing 7 to $8.5 \mathrm{~mm}$. long. L. americana (Leach) .

5. American and Pacific species. Postvertex rather long; the anterior angles broadly rounded off, the anterior margin about as long as each of the sides. Wing 7.5 to $8.5 \mathrm{~mm}$. long L. nigra (Perty). African species. Postvertex rather short, more transverse; the anterior angles more abruptly rounded off, the anterior margin much longer than each of the sides. Wing 8 to $8.5 \mathrm{~mm}$. long .......L. dukei (Austen).

In the foregoing key the terms "postvertex" and "fronto-clypeus" are used as defined by Jobling. The postvertex corresponds to the "vertical plate" or "vertex" of most authors, being the hard, smooth area in the upper part of the frons, limited behind by the occipital margin.

\section{Lynchia pilosa (Macquart)}

Olfersia pilosa Macquart, 1843, Mém. Soc. Sci. Lille, (1842), p. 434.(no sex; Africa, without more definite locality; but since the type was collected by Delalande, it must have come from South Africa) ; 1843, Dipt. Exot., II, pt. 3, p. 277 . Neave, 1912, Bull. Ent. Res., III, pp. 317, 320 and 322. Morstatt, 1913, Der Pflanzer, IX, p. 509.

Lynchia pilosa Falcoz, 1930, Encyclop. Entom., Diptera, V, p. 48. Bedford, 1932, 18th Rept. Director Vet. Serv. Animal Ind. Union S. Africa, p. 424.

Specimens Examined.-Orange Free State: Hoopstad, one female (H. Brauns).-Abyssinia: Ouache (= Hawash River?), one male (Paris Museum).

This remarkable species is readily recognizable by the peculiar pilosity of the thorax and the hyaline, extensively bare wings.

The present location of the type is unknown. The hosts are species of bustards, according to G. A. H. Bedford (1932), who records L. pilosa off the Kori, Choriotis kori 
(Burchell), in Zululand; the White-quilled Black Knorhaan, Afrotis atra afraoides (A. Smith), in Transvaal; and the Greater Bustard, either Choriotis kori struthiunculus (Neumann) or Neotis cafra jacksoni Bannerman, in Kenya Colony.

\section{Lynchia palustris (Lutz, Neiva and da Costa Lima)}

Olfersia palustris Lutz, Neiva and da Costa Lima, 1915, Mem. Inst. Osw. Cruz, VII, p. 183, Pl. XXVIII, fig. 4 (no sex; off Herodias egretta, Tigrisoma brasiliense, Cancroma cochlearia and Harpiprion cayennensis, State of Piauhy; off a white heron, Rio de São Francisco, Brazil: and off Ardea socoi, Lassance, State of Minas Geraes). Ad. Lutz, 1928, Est. Zool. Paras. Venezolanas, p. 9.

? Olfersia americana Massonnat, 1909, Ann. Univ. Lyon, N. S., CXXVIII, p. 304, Pl. V, figs. 40-42 ( + ). Not of Leach.

? Ornithoponus massonnati Falcoz, 1926, Faune de France, XIV, Diptères Pupipares, p. 31, figs. 28-29 ( 9 ; off Platalea leucorodia; region of the Dombes, Ain, France).

SPECIMEN ExAmined.-Belgian Congo: Mongende, one male; off a Cormorant, Phalacrocorax africanus (Gmelin), April 14, 1921 (H. Schouteden).

I am unable to separate this African specimen from $L$. palustris, commonly found in South America on wading birds. The species appears to be most closely related to L. hirsuta Ferris, of North America; but that fly is much smaller (wing $5 \mathrm{~mm}$. long), has the basal cell relatively shorter, three long setæ on each half of prescutum, and a long prescutellar on each side. I find no such setæ in my specimen of L. palustris. L. botaurinorum Swenk, which I have seen from Brazil, as well as from North America, likewise differs from $L$. palustris in the smaller size (wing $5 \mathrm{~mm}$. long).

$L$. palustris is readily differentiated from $L$. ardeæ (Macquart) and related species, found more commonly on wading birds, by the larger size, the much wider fronto-clypeus, and the absence of setæ over an extensive median area on the dorsal face of the abdomen. 
SYNONYMY.-The name Ornithoponus massonnati was introduced by Falcoz for the fly from France which Massonnat (1909) described and figured as "Olfersia americana," (the type probably in the collections of the University at Lyons). Ferris and Cole (1932) were quite justified in concluding that Massonnat's insect was probably "an entirely distinct species" from "americana." Among the larger species of Lynchia (Massonnat gives the length of the wing as $8.2 \mathrm{~mm}$.) known to me, Massonnat's description agrees best with $L$. palustris, although the hairs of the inner orbital plates and the peculiar setulose covering of the wing membrane are not mentioned by him nor by Falcoz. There are some features of Massonnat's drawings, such as the very wide frons, that do not fit $L$. americana, though some of them might be due to inaccuracies (there are striking differences between the drawings of the head in figures 40 and 42 , particularly in the outline of the postvertex and the trend of the sides of the frons). In addition, Massonnat's fly was taken off a white spoonbill, Platalea leucorodia, and thus far I have never seen specimens of true L. americana taken from a wading bird. In view of the fact that L. palustris has now been found on a cormorant in Africa, it seems highly probable that Ornithoponus massonnati is the same species.

\section{Lynchia americana (Leach)}

Feronia americana Leach, 1817, Gen. Spec. Eprobosc. Ins., p. 11, Pl. XXVII, figs. 1-3 (no sex; no host; Georgia, North America). Austen, 1903, Ann. Mag. Nat. Hist., (7) XII, p. 264 (type at Brit. Mus.). Lutz, Neiva and da Costa Lima, 1915, Mem. Inst. Osw. Cruz, VII, p. 188.

Olfersia americana Wiedemann, 1830, Aussereurop. Zweifl. Ins., II, p. 606. Macquart, 1835, Hist. Nat. Ins. Dipt., II, p. 641. T. W. Harris, 1835, in Hitchcock, Rept. Geol. Miner. Zool. Bot. Massachusetts, 2d Ed., p. 600. Walker, 1849, List Dipt. Brit. Mus., IV, p. 1141. Osten Sacken, 1858, Cat. Dipt. North America, p. 86. v.d. Wulp, 1867, Tijdschr. v. Entom., X, p. 128. Osten Sacken, 1878, Cat. Dipt. North America, 2d Ed., p. 213. C. W. Johnson, 1900, 27th Rept. New Jersey Bd. Agric., (1899), Suppl., 
p. 699. Aldrich, 1905, Cat. North Amer. Dipt., p. 655. Speiser, 1907, Ent. News, XVIII, p. 104. Swenk, 1916, Jl. New York Ent. Soc., XXIV, p. 130. W. E. Britton, 1920, Conn. Geol. Nat. Hist. Surv., Bull. 31, p. 210. Cole and Lovett, 1921, Proc. California Ac. Sci., (4) XI, p. 344. W. T. Davis, 1922, Proc. Staten Island Inst. Arts Sci., I, p. 65. C. W. Johnson, 1922, Psyche, XXIX, p. 83. Ornithoponus americanus Aldrich, 1923, Insecutor Insc. Menstr., XI, pp. 77 and 78. C. W. Johnson, 1925, Proc. Boston Soc. Nat. Hist., XXXVIII, p. 99; 1925, Bull. Northeast. Bird-Banding Assoc., I, p. 52; 1925, Occas. Pap. Boston Soc. Nat. Hist., VII, p. 293. Gross, 1925, The Auk, XLII, p. 431. C. W. Johnson, 1927, Bull. Boston Soc. Nat. Hist., No. 42, p. 15. O. A. Johannsen, 1928, in Leonard, List Insects New York, (1926), p. 868.

Lynchia americana Falcoz, 1930, Encyclop. Entom., Diptera, V, p. 48 (in part?). C. W. Johnson, 1929, Bull. Northeast. Bird-Banding Assoc., V, p. 52. Ferris, 1930, Canad. Entom., LXXII, p. 67, fig. 5A, D, and F.

Hippobosca bubonis Packard, 1869, Guide to the Study of Insects, 1st Ed., p. 417 (no sex; off Great Horned Owl; Massachusetts). Copied without change in all later editions.

? Ornithomyia villadæ Dugès, 1887, La Naturaleza, Mexico, (2) I, pt. 1, p. 20, Pl. III, fig. 3 (no sex; off Buteo calurus and $B$. bairdii; somewhere in Mexico; no definite locality given).

?Olfersia villadæ van der Wulp, 1903, Biol. Centr. Amer., Diptera, II, p. 430. Aldrich, 1905, Cat. North Amer. Dipt., p. 656.

The following references to "Olfersia americana" are doubtful or erroneous.

Olfersia americana Ferris and Cole, 1922, Parasitology, XIV, p. 194, figs. 11-12 ( 9 ; off Tyto alba pratincola; San Bernardino, California). To judge from fig. 11, the frons is distinctly less than twice the width of an eye and has subparallel sides; while the postvertex is rather long in the middle, with broadly rounded angles. Most probably this specimen was what I call L. fusca (Macquart). 
Lynchia americana Ferris, 1927, Canad. Entom., LIX, p. 248, figs. 2 and 3 (fig. 3 erroneously labelled "L. hirsuta"; corrected by Ferris, 1929, Ibidem, LXI, p. 285) ( $q$; off Otus asio; Monticito, California). The same remark applies to this as to the foregoing record.

Ornithoponus americanus C. W. Johnson, 1924, Zoologica, New York, V, No. 8, p. 91 (off Buteo galapagoensis; Seymour Bay, Indefatigable, Galapagos). I have seen this fly, which is L. nigra (Perty). Curran's O. americanus, from Santa Cruz, Indefatigable, (1932, Nyt Mag. Naturvid., LXXI, p. 366), probably also was $L$. nigra, but I have not seen the specimen.

Olfersia americana C. W. Johnson, 1895, Proc. Ac. Nat. Sci. Phila., p. 340 (off Screech Owl, Otus asio floridanus; St. Petersburg, Florida). I have seen this specimen, which is L. fusca (Macquart).

Olfersia americana C. W. Johnson, 1913, Bull. Amer. Mus. Nat. Hist., XXXII, p. 90 (St. Augustine and Miami, Florida). These specimens, seen by me, are $L$. fusca (Macquart).

SPECIMENS EXAMINED.-L. americana is perhaps the most common of the North American hippoboscids. I have seen over one hundred specimens from the following localities. Ontario: Point Pelee.-Nova Scotia: Annapolis.-Maine: Kittery Point.-New Hampshire: Candia; Hampton.-Vermont: Dunmore Lake.-Massachusetts: Boston; Wenham; Middleboro; West Tisbury; Framingham; Monterey; Dover; Sherborn; Princeton; Chicopee.-Connecticut: Liberty Hill.-New York: Long Island; Staten Island; Freeport; Yankee Lake, Wurtsboro, Sullivan Co.; Austerlitz; Ithaca; West Point; Albany; Sparta; Clarksville; Albany Co.; Baldwinsville; Carmel.-New Jersey: Ramsey; Haddanfield; Stag Lake, Sussex Co.; Kittatinny Mts.-Pennsylvania: Eschol; Penfield; Dauphin Co.; Philadelphia; Shirleysburg; Pike Co.; Harrisburg.-Virginia: Urbana.North Carolina: Raleigh.-South Carolina: Charleston; Dewees Island; Society Hill.-Florida: St. Augustine.Ohio: Licking Co.; Crestline; Wauseon.-Indiana: Indianapolis.-Illinois: Warsaw.-Wisconsin: W. Spring Green; Ripon.-Iowa: Iowa City._Kansas: Clay Co.; Douglas Co. 
-Texas: Dallas.-Nevada: without more definite locality. -Mexico: Grito (in which State?).-In addition there are reliable published records from Washington, D. C., Georgia, Nebraska and Kentucky.

The host list is a very large one, including owls, hawks and other birds of prey, as well as grouse: Great Horned Owl, Bubo virginianus (Gmelin), (very common on several subspecies) ; Barred Owl, Strix varia Barton; Long-eared Owl, Asio wilsonianus (Lesson); Barn Owl, Tyto alba pratincola (Bonaparte); Screech Owl, Otus asio (Linnæus) ; Pigeon Hawk, Falco columbarius Linnæus; Sharpshinned Hawk, Accipiter velox (Wilson) ; Red-tailed Hawk, Buteo borealis (Gmelin); Broad-winged Hawk, Buteo platypterus (Vieillot); Rough-legged Hawk, Buteo lagopus sancti-johannis (Gmelin); Red-shouldered Hawk, Buteo lineatus (Gmelin); Western red-tailed Hawk, Buteo borealis calurus (Cassin); Marsh Hawk, Circus hudsonius (Linnæus); Cooper's Hawk, Accipiter cooperi (Bonaparte) ; Golden Eagle, Aquila chrysaëtos (Linnæus) ; Goshawk, Astur atricapillus (Wilson); and Ruffed Grouse, Bonasa umbellus (Linnæus). At the Mus. Comp. Zoöl. there is also an old specimen, without locality, labelled "off wild turkey." Sometimes the parasite is very abundant. C. W. Johnson records a Great Horned Owl that yielded 32 flies and some pupæ, the latter hidden in the ears.

Owing to frequent confusion with related species (particularly with $L$. $f u s c a$ ), some previously published records of hosts and localities are unreliable. Two old specimens labelled "Nevada" at the Mus. Comp. Zoöl., and one specimen from St. Augustine, Florida, in the C. W. Johnson Collection, are true $L$. americana. But all other specimens I have seen from west of the Rockies and from Florida were L. fusca. Published records from Oregon (Cole and Lovett, 1921, Proc. California Ac. Sci., (4) XI, p. 344 ; Falcoz, 1930, Encyclop. Entom., Diptera, V, p. 48), and California (C. W. Johnson, 1922, Psyche, XXIX, p. 83; in addition to those mentioned before), are all open to question. There is one definite record of $L$. americana from Mexico, but how widely it is distributed there is unknown. Falcoz' indication "Columbia" refers to Washington, D. C., not to British 
Columbia nor to Colombia. There is as yet no conclusive evidence that L. americana occurs in Europe, as shown in the discussion of $L$. palustris.

SYNONYMY.-The type of Feronia americana (Leach) is at present at the British Museum and it is reasonably certain that it agrees with the characters here given for the species.

That Hippobosca bubonis (Packard) is identical with $L$. americana (Leach), was recognized by Osten Sacken as early as 1878. The type, which I have seen at the Museum of Comparative Zoölogy, shows the correctness of this synonymy.

From the description alone it is difficult to recognize Ornithomyia villadæx Dugès, (the type of which is probably lost), although there can be no doubt about its being a Lynchia. For a time I believed that it might be L. nigra (Perty), and I have named specimens of $L$. nigra, in some collections, "villadro." Recently, however, I received, from the Department of Entomology of Kansas University, a fly taken off Buteo borealis calurus at Grito, Mexico, and bearing a manuscript label "resemble à Ornithomyia villadæx A. Dug." This specimen agrees in every respect with the North American L. americana. I am, therefore, listing villadx, provisionally at any rate, in the synonymy of americana, pending the examination of further Mexican material.

\section{Lynchia fusca (Macquart)}

Olfersia fusca Macquart, 1845, Mém. Soc. Sci. Lille, (1844), p. 346 (no sex; Nouvelle Grenade = Colombia) ; 1846, Dipt. Exot., Suppl. I, p. 218. Speiser, 1902, Zeitschr. Syst. Hym. Dipt., II, p. 177 (description of type). Lutz, Neiva and da Costa Lima, 1915, Mem. Inst. Osw. Cruz, VII, pp. 182, 189 and 194 (doubtful records). Bau, 1929, Zoolog. Anzeiger, LXXXV, p. 10.

Lynchia fusca Falcoz, 1930, Encyclop. Entom., Diptera, V, p. 47.

? Olfersia macquartii Rondani, 1878, Ann. Mus. Civ. Genova, XII, p. 160 (no sex; New Grenada=Colombia; based upon a specimen received as "fusca" from Mac- 
quart, but claimed to be of a different species). Lutz, Neiva and da Costa Lima, 1915, Mem. Inst. Osw. Cruz, VII, p. 190.

? Olfersia wolcotti Swenk, 1916, Jl. New York Ent. Soc., XXIV, p. 132 (no sex; off Buteo platypterus; Ann Arbor, Michigan).

Specimens Examined.-Florida: St. Augustine, off a Screech Owl, Otus asio floridanus (Ridgway) (C. W. Johnson); Miami (P. Laurent).-Colorado: one female without more definite locality (Ks. Univ. Ent. Mus.).-California: several specimens off Burrowing Owl, Speotyto cunicularia hypogea Bonaparte, and off Californian Screech Owl, Otus asio mecalli (Cassin), without more definite locality ( $\mathrm{H}$. Edwards.-M. C. Z.) ; San José, Santa Clara Co., off Great Horned Owl, Bubo virginianus pacificus Cassin, and off Barn Owl, Tyto alba tuidara J. E. Gray, three specimens (G. A. Allen).-Also several specimens, without localities, in the old Osten Sacken Collection at the M. C. Z.

The specimens from Florida, here listed as $L$. fusca, were recorded by C. W. Johnson (in 1895, 1913, and 1922) as L. americana. As suggested above, most previous records of L. americana from California and Oregon were probably based on L. fusca.

The differences between $L$. fusca and $L$. americana, mentioned in my key, may seem trifling. Yet they appear to be constant and in the large series of both species studied I have seen no specimen of doubtful identity. A repeated and careful study of my material has failed to disclose other reliable characters. The following peculiarities may, however, be of some value. (1) The frons is usually narrower in $L$. fusca than in L. americana, although the width seems to be variable in both species; in most fusca it is less than one and a half times as wide as the eye; in most americana it is one and a half times to twice as wide as the eye. The apical, flaring arms of the fronto-clypeus appear to be less spreading in fusca than in americana. (3) The color of body and legs is as a rule more uniform and darker mahogany brown in fusca, lighter and blotched in americana, while the wings of fusca lack the slight yellowish tinge of americana. 
SyNONYMY.-That the flies here called L. fusca are specifically distinct from $L$. americana can hardly be doubted. A specimen without locality, received from the Zoölogical Institute of Halle a.S. (through Dr. Vult Ziehen), had been named "fusca Macquart" by the late A. Bau and this identification appears to be correct. Macquart's species could not possibly be recognized from the original description. Fortunately, Speiser has fully redescribed the type (from the Bigot Collection, now in the possession of Mr. J. E. Collin), and his account tallies well with the specimens listed above.

I am inclined to regard Olfersia wolcotti (type in the Dept. of Zoölogy, University of Nebraska at Lincoln, Nebraska), as a synonym of $L$. fusca. Swenk's brief description agrees with my specimens, except for his statement that the frons is "not wider than the breadth of an eye." In all my specimens of $L$. fusca, the frons is distinctly, though often only very slightly, wider than an eye.

Falcoz (1930) lists as synonyms of $L$. fusca both Olfersia macquartii Rondani and (with doubt) O. angustifrons v.d. Wulp. With regard to angustifrons, I follow Swenk, who places it among the smaller species and I have seen several specimens from Central America that agree in every respect with the original description. It appears to be a perfectly valid species. It is more difficult to decide what to do with $O$. macquartii (location of type unknown). Rondani received it from Macquart under the name "fusca" (but it was not Macquart's type, although it came from the same locality), and claimed that it did not agree with the original description of that species. Speiser (1902), in his discussion of the type of $O$. fusca, regards macquartii as distinct, but he points out only one difference: "Scheitel ... in der Mitte des Vorderrandes mit einem seichten grubenförmig tiefen Einschnitt (Abweichung gegenüber O. macquartii Rond.)." This, however, is erroneous, since Rondani states in his description: "area verticale antice in medio incisa." Rondani's type does not appear to have been studied again.

As indicated below, Olfersia raptatorum Lutz, Neiva and da Costa Lima is probably also a synonym of $L$. fusca.

Ornithomya fusca "Macquart" Percheron, 1838, in 
Guérin and Percheron, Genera des Insectes, $6^{\circ}$ Livr., No. 9, Diptères, Pl. VI (no sex; with description, without locality), has evidently nothing in common with Olfersia fusca Macquart. The very large size (length 5 lines $=11 \mathrm{~mm}$.), and the statement that ocelli were present, would seem to point to a species of Ornithoctona. The figures, it is true, do not show the closed anal cell, but this may be due to an oversight. It should, moreover, be noted that some at least of the detail drawings were made from Ornithomyia avicularia.

\section{Lynchia nigra (Perty)}

Hippobosca nigra Perty, 1833, Delectus Anim. Artic. Brasil., III, p. 190, Pl. XXXVII, fig. 15 (no sex; no host; State of Piauhy, Brazil).

Pseudolfersia nigra Austen, 1903, Ann. Mag. Nat. Hist., (7) XII, p. 266.

Olfersia nigra Speiser, 1905, Zeitschr. Syst. Hym. Dipt., V, p. 356. Lutz, Neiva and da Costa Lima, 1915, Mem. Inst. Osw. Cruz, VII, p. 181 (doubtful records).

Ornithomyia intertropica Walker, 1849, List. Dipt. Brit. Mus., IV, p. 1144 (no sex; Galapagos). Lutz, Neiva and da Costa Lima, 1915, Mem. Inst. Osw. Cruz, VII, p. 189. Olfersia intertropica Austen, 1903, Ann. Mag. Nat. Hist., (7) XII, p. 264. Aldrich, 1905, Cat. North Amer. Dipt., p. 655. Speiser, 1907, Ent. News, XVIII, p. 104. Austen, 1911, Bull. Ent. Res., II, p. 172, footnote.

Lynchia intertropica Ferris, 1930, Canad. Entom., LXXII, p. 69 , fig. $5 B, C$, and $H$.

Olfersia acarta Speiser, 1902, Zeitschr. Syst. Hym. Dipt., II, p. 149 (no sex; type from Molokai; also from "shorteared owl" in Kona, and from Lanai; all Hawaiian Islands) ; 1902, Fauna Hawaiiensis, III, p. 87 (same localities; it is claimed here that the type, from Molokai, was found on a Frigate bird, Fregata aquila, a statement not made in the other paper). Alfken, 1904, Zool. Jahrb., Abt. Syst., XIX, p. 572.

The following references do not refer to true $O$. nigra, as here recognized:

Olfersia intertropica Swenk, 1916, Jl. New York Ent. 
Soc., XXIV, pp. 129 and 133 (specimen from Orizaba, Mexico). Since Prof. Swenk places his intertropica in the group of small species, the specimen could not have been Walker's intertropica. It was probably either Lynchia albipennis (Say) or a closely allied species.

Ornithoponus intertropicus C. W. Johnson, 1924, Zoölogica, New York, V, No. 8, p. 91 (off Butorides sundevalli; Seymour Bay, Indefatigable, Galapagos) ; quoted by Curran, 1932, Nyt Mag. Naturvid., LXXI, p. 366. I have seen this specimen; it belongs to one of the smaller species, related to Lynchia albipennis (Say).

SPECIMENs ExAmineD.-Prov. Quebec: Kamouraska (au Moulin), Kamouraska Co., off Duck Hawk, Falco peregrinus anatum Bonaparte (W. LaBrie.-Dept. Agr. Canada, Ent. Br.).-Colorado: Denver, off Red-tailed Hawk, Buteo borealis calurus (Cassin) (W. H. Bergtold).- Montana : Truman Siding, Ravalli Co., off Red-tailed Hawk, Buteo borealis calurus (Cassin) (C. B. Philip).-New Mexico: (U. S. N. M.).--Texas : Elkhart, off a hawk (U. S. N. M.). -Mexico: one female without definite locality (A. Dugès.Paris Mus.; specimen doubtfully referred to Olfersia raptatorum by Falcoz, 1930) ; Mexico City (U. S. N. M.).-Panama: Pacora, off Mexican Black Hawk, Buteogallus (or Urubitinga) anthracina anthracina (Lichtenstein) (L. H. Dunn).-Brazil: holotype, without more definite locality (Zoöl. Mus. Munich) ; Rio São Francisco, State of Bahia, off a hawk No. 1004 (J. A. Allen, Thayer Exped.-M. C. Z.).--Bolivia: Province Sara, one female (Steinbach.M. C. Z.).-Galapagos Islands: Indefatigable Island, several specimens, off Buteo galapagoensis (Gould) (J. P. Chapin, Astor Exped.-Am. M. N. H.).-Hawaiian Islands : Kanai, off an owl (E. Knudsen).

SYNONYMY.-Through the kindness of Dr. E. O. Engel, I have been able to study Perty's type of Hippobosca nigra, now preserved at the Bavarian Zoölogical Museum, Munich. I find that it is specifically identical with Walker's Ornithomyia intertropica and Speiser's Olfersia acarta.

\section{Lynchia dukei (Austen)}

Olfersia dukei Austen, 1911, Bull. Ent. Res., II, p. 171 ( ; 
off Haliætus vocifer (Daudin) ; Nsadzi Island, Lake Victoria, Uganda). Neave, 1912, Ibidem, III, p. 322.

Lynchia dukei Falcoz, 1930, Encyclop. Entom., Diptera, V, p. 48.

Ornithomyia nigricans C. W. Johnson, 1898, Proc. Ac. Nat. Sc. Philadelphia, p. 164. Not of Leach.

SPECIMENS Examined.-Belgian Congo: Kwamouth (J. Maes) ; Ganda Sundi, two specimens off a bird of prey ( $\mathrm{H}$. Schouteden) ; M'Bamu Island in the Stanley Pool, one male (E. Roubaud.-Paris Museum) ; Elisabethville, three females off Bateleur Eagle, Terathopius ecaudatus (Daudin) (J. De Riemaecker).-Abyssinia: Dada, near the Daroli River, one male and one female (A. D. Smith.-Ac. Nat. Sc. Phila.; specimens recorded by Johnson, 1898, as $O$. nigricans).

This species, the type of which is at the British $\mathrm{Mu}-$ seum, is exceedingly close to L. nigra (Perty) and I am by no means satisfied that it is distinct. Austen writes that it is distinguishable from Olfersia intertropica (Walker) (a synonym, in my opinion, of L. nigra) "by its more elongate and darker palpi, by the hairs and punctures on the inner borders of the sides of the front being fewer in number and coarser, and especially by the different shape of the shining plate on the vertex, which is more transversely elongate, and the anterior angles of which are more abruptly rounded off." Of these differences, only the shape of the postvertex (as indicated in my key) seems reliable in the series of dukei and nigra studied. The length of the palpi in dried specimens varies with the retraction of the proboscis; and I can detect no difference in the number and coarseness of the hairs on the inner orbits of perfectly preserved specimens (the punctures being the insertions of the hairs). Austen gives the length of the wing as $9.4 \mathrm{~mm}$., but this must be unusual, since the wing in my specimens reaches at most $8.5 \mathrm{~mm}$. in length.

\section{Lynchia penelopes Weyenbergh}

Lynchia penelopes Weyenbergh, 1881, Anales Soc. Cientif. Argentina, XI, p. 199 ( $q$ ô ; off Penelope canicollis Wagler; Province of Tucuman, Argentina). Brèthes, 1907, 
An. Mus. Nac. Buenos Aires, XVI, p. 302. Speiser, 1908, Zeitschr. Wiss. Insektenbiol., IV, p. 304. J. Bequaert, 1926, Psyche, XXXII, (1925), p. 270.

This species has not been recognized thus far, but, from the description and the host, it is evidently quite distinct from any of the foregoing. If Weyenbergh's measurements are correct (spread of wings, $2.5 \mathrm{~cm}$., corresponding to a wing length of 10 to $11 \mathrm{~mm}$.), the large size alone should enable one to recognize it.

Lynchia raptatorum (Lutz, Neiva and da Costa Lima)

Olfersia raptatorum Lutz, Neiva and da Costa Lima, 1915,

Mem. Inst. Osw. Cruz, VII, p. 181, Pl. XXVIII, fig. 3 (no sex; off Polyborus tharus, Milvago chimachima and Leucopternis palliata in several States of Brazil; and off Cathartes aura, State of Piauhy, Brazil). Ad. Lutz, 1928, Est. Zool. Paras. Venezolanas, p. 9.

The length of the wing $(7.5$ to $8 \mathrm{~mm}$.) places $L$. raptatorum in the group here under discussion. It is probably either L. fusca (Macquart) or L. nigra (Perty), both of which are found on birds of prey. The original description is insufficient to decide the point, but the probabilities are rather for $L$. fusca. 

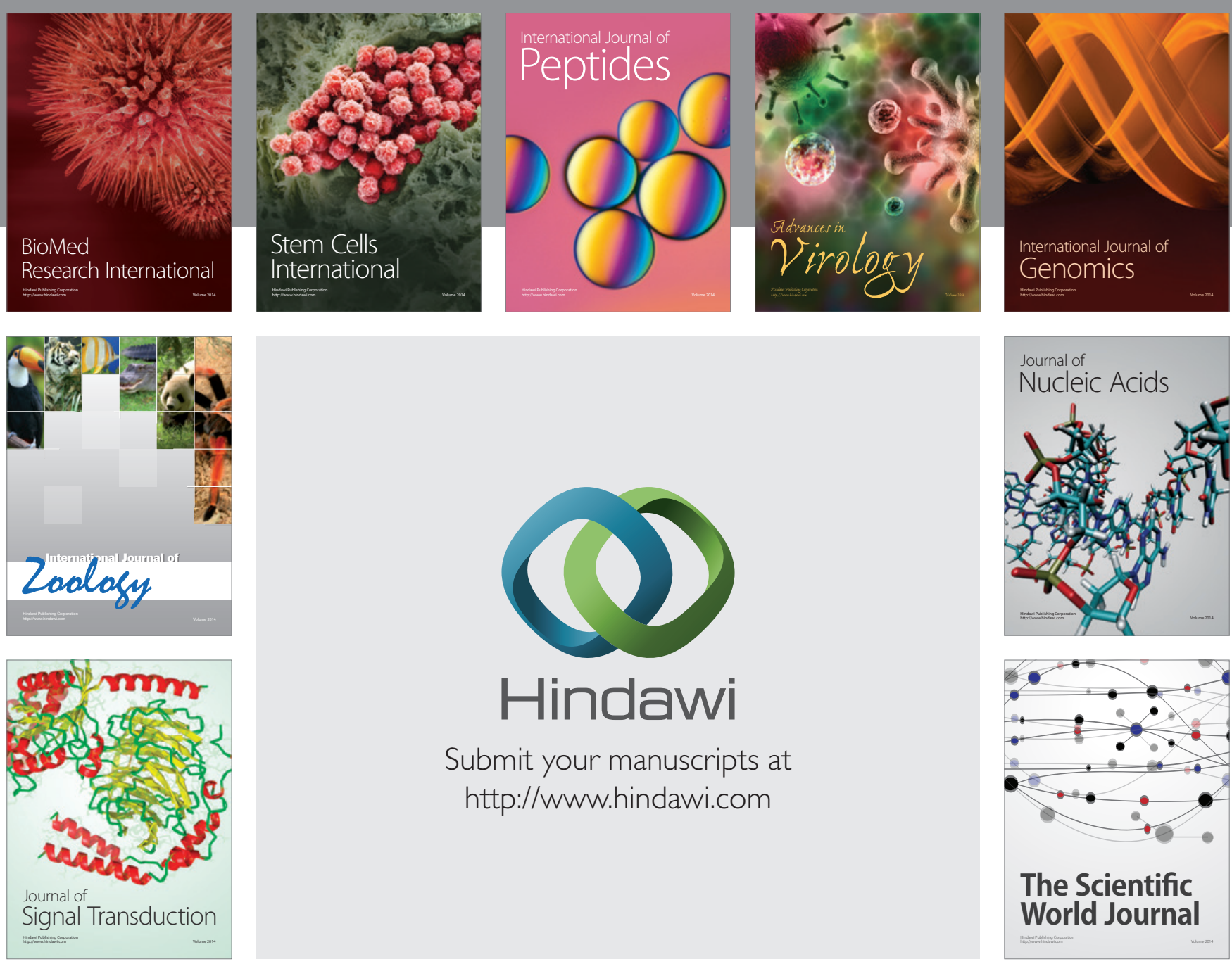

Submit your manuscripts at

http://www.hindawi.com
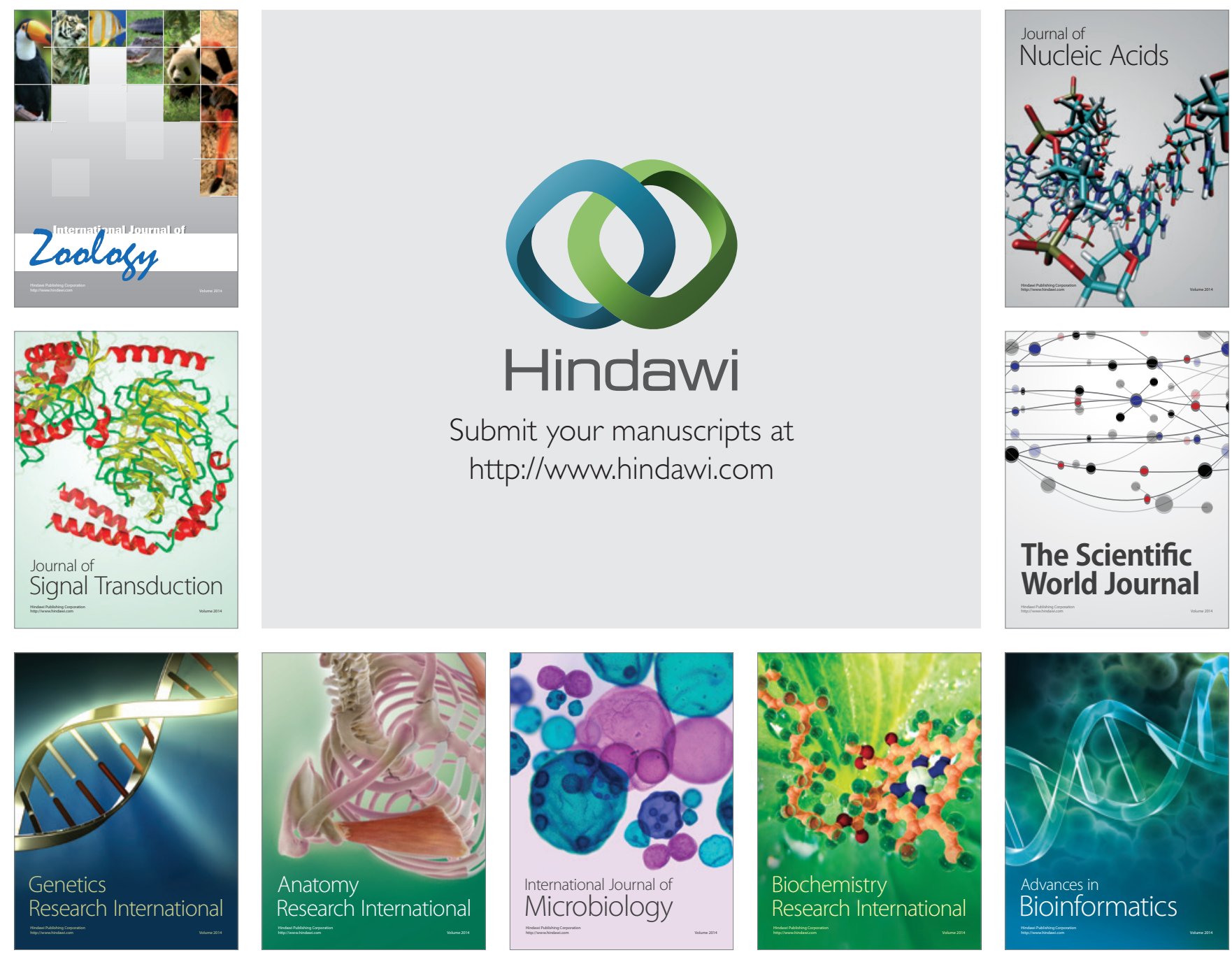

The Scientific World Journal
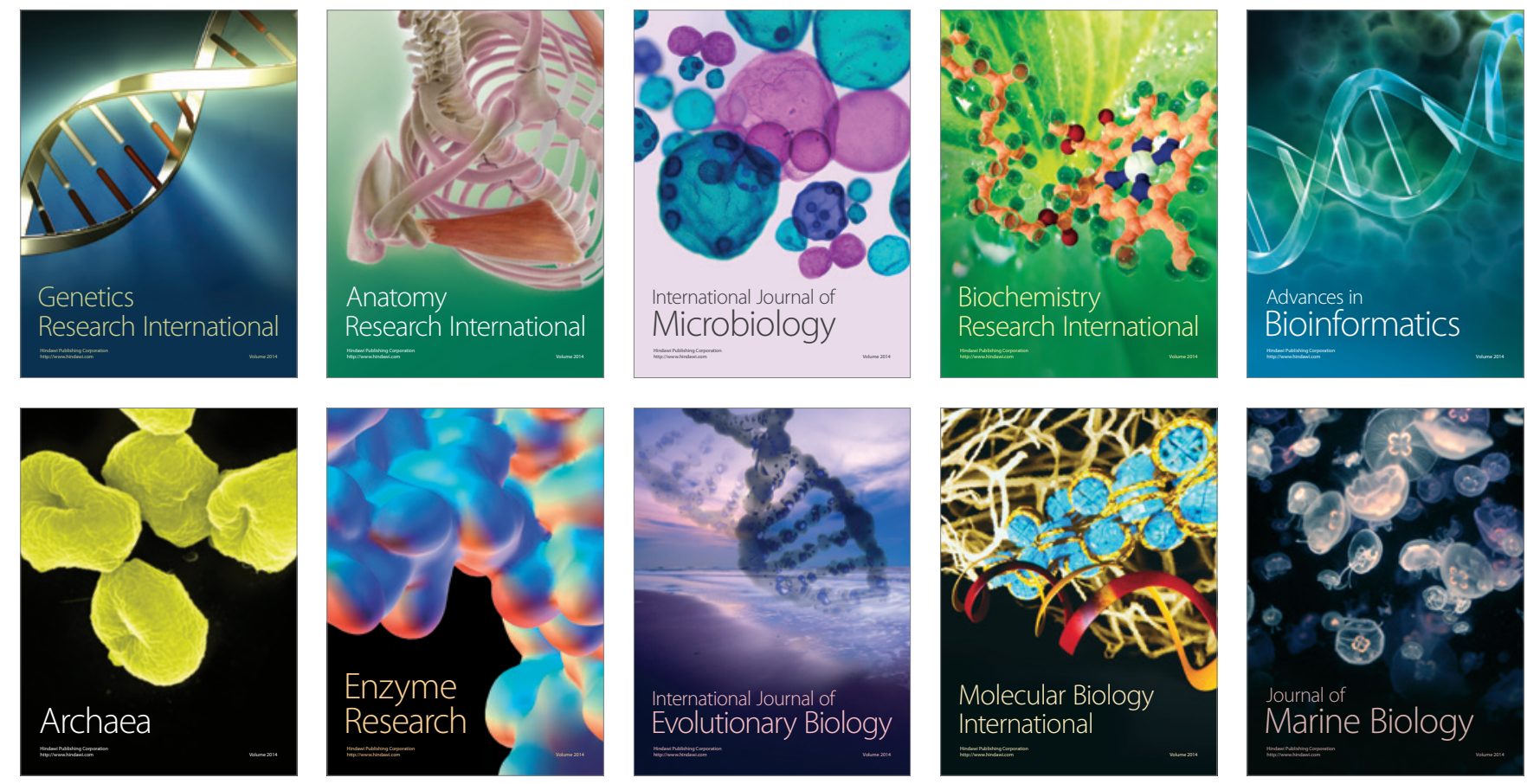